\title{
PROGRAM EDUKASI MASYARAKAT DALAM USAHA MENINGKATKAN PENGETAHUAN TENTANG PENTINGNYA OLAHRAGA DI MASA PANDEMI COVID-19
}

\author{
Arrasy Khawarizmi ${ }^{1}$, Clara Alverina ${ }^{2}$, Caesariska Deswima ${ }^{3}$, Reny I'tishom ${ }^{4^{*}}$ \\ ${ }^{1-4}$ Universitas Airlangga \\ Email Korespondensi: ritishom@fk.unair.ac.id
}

Disubmit: 07 Januari 2022

Diterima: 13 Januari 2022

Diterbitkan: 01 Februari 2022 DOI: https://doi.org/10.33024/jkpm.v5i2.5769

\begin{abstract}
ABSTRAK
Pandemi COVID-19 membawa perubahan pada seluruh aspek termasuk kegiatan olahraga. Transmisi virus yang cepat berdampak pada pembatasan aktivitas. Meskipun demikian, olahraga merupakan salah satu gaya hidup sehat yang tetap harus dilakukan. Maka dari itu, diperlukan edukasi yang tepat dalam berolahraga di masa pandemi COVID-19 supaya tetap bisa berolahraga dan terhindar dari COVID-19. Kegiatan edukasi dilakukan melalui platform Instagram supaya menjangkau masyarakat luas. Sebelumnya, survei juga turut dilakukan sebagai landasan kegiatan edukasi. Hasil intervensi kegiatan edukasi menunjukkan adanya peningkatan pemahaman hingga tiga kali lipat berdasarkan hasil posttest dibandingkan dengan pre-test. Evaluasi kegiatan ini yang dilakukan menggunakan kuesioner yang dibagikan kepada para responden menunjukkan sebagian besar responden memberikan penilaian yang sangat baik terhadap materi yang dibawakan $(64,7 \%)$, kesesuaian materi terhadap kondisi pandemi $(76,47 \%)$, serta kebermanfaatan acara $(73,52 \%)$. Dengan adanya peningkatan pemahaman ini, maka peningkatan dalam melakukan olahraga di masa pandemi COVID-19 dapat terjadi.
\end{abstract}

Kata Kunci : COVID-19, edukasi, olahraga, olahraga saat pandemi

\section{ABSTRACT}

The COVID-19 pandemic has effects for all aspects including sports activities. The rapid transmission of the virus has an impact on activity restrictions. However, sport is a healthy activity that must be done. Therefore, proper education is needed in exercising during the COVID-19 pandemic so that you can still exercise and avoid COVID-19. Educational activities are carried out through the Instagram platform so that the reach can be broad. Public surveys are also carried out as a basis for the topic. The results of the education intervention showed an increase in understanding up to three times based on the results of the post-test compared to the pre-test. The evaluation of this activity which using a questionnaire distributed to the respondents showed that most of the respondents gave a very good assessment of the topic presented (64.7\%), the suitability of the topic to pandemic conditions (76.47\%), and the usefulness of the activity $(73,52 \%)$. The increase of understanding topics can increase in doing sports during the COVID-19 pandemic.

Keywords : COVID-19, education, exercise, exercise during pandemic 


\section{PENDAHULUAN}

Masa pandemi COVID-19 membawa perubahan dalam kehidupan masyarakat. Penularann virus SARS-COV-2 utamanya adalah melalui droplet dari orang terinfeksi ke orang lain (Guan et al., 2020). Oleh sebab itu, selama pandemi COVID-19, terjadi pembatasan mobilitas dan kegiatan masyarakat untuk mencegah dan mengurangi transmisi virus SARS-COV-2 ini. Semua harus dilakukan di rumah mulai dari belajar, bekerja, beribadah, bahkan olahraga juga turut dianjurkan di rumah (Yuliana, 2020). Hal ini menyebabkan sebagian besar kegiatan di masa pandemi di lakukan di rumah saja dan aktivitas fisik masyarakat menjadi berkurang. Walaupun selama masa pandemi ini aktivitas di luar ruangan tidak disarankan namun olahraga tetap harus dilakukan (Wicaksono, 2020). Untuk membantu mengurangi penyebaran COVID-19, CDC menganjurkan untuk tetap berada di rumah dengan merekomendasikan aktivitas fisik harian untuk anakanak (60 menit/hari) dan orang dewasa (30 menit/hari) (Lim \& Pranata, 2021).

Berkurangnya aktivitas fisik menyebabkan peningkatan risiko kenaikan berat badan karena penggunaan energi yang lebih rendah. Selain itu, berkurangnya interaksi sosial secara langsung dapat meningkatkan kecemasan dan menimbulkan perasaan tertekan (Fallon, 2020). Studi oleh Brand et al. (2020) menunjukkan bahwa 44,2\% peserta tidak mengalami perubahan frekuensi latihan, 23,7\% melaporkan penurunan frekuensi latihan, dan 31,9\% melaporkan peningkatan frekuensi latihan selama pandemi COVID-19. Praktek gaya hidup sehari-hari yang aktif melalui kegiatan fisik dianjurkan untuk menurunkan konsekuensi kesehatan dan mental akibat pandemi COVID-19 (Lim \& Pranata, 2021). Aktivitas fisik yang rutin perlu dilanjutkan di masa pandemi COVID-19 karena dapat menjaga dan meningkatkan fungsi sistem kekebalan tubuh (Chen et al., 2020). Menurut WHO, aktivitas fisik yang dilakukan secara teratur sangat penting untuk mencegah dan mengobati penyakit tidak menular yang dapat meningkatkan dan menjaga kesehatan mental, kualitas hidup, kesejahteraan, dan meningkatkan kualitas proses penuaan (Vancini et al, 2021).

Berolahraga dapat di rumah menggunakan berbagai latihan yang aman, sederhana, dan mudah diterapkan sangat cocok untuk menghindari virus corona di udara dan menjaga tingkat kebugaran (Chen et al., 2020). Dalam melakukan olahraga perlu adanya motivasi yang kuat dari diri sendiri. Namun kendala yang dialami adalah memulai dan menjaga komitmen motivasi berolahraga. Motivasi adalah penggerak seseorang dalam melakukan sesuatu yang salah satunya adalah olahraga. Motivasi orang dalam melakukan aktivitas fisik atau olahraga adalah berawal karena faktor kesehatan, mengurangi berat badan,kebugaran, dan ingin mencari tantangan. Selanjutnya alasan olahraga dapat menjadi kesenangan, aktivitas sehari-hari ataupun juga faktor sosial (Firdaus, 2012). Maka dari itu di masa pandemi ini diperlukan motivasi yang tepat untuk memulai olahraga, selanjutnya melakukannya dengan benar sesuai protokol kesehatan, dan yang terpenting berkomitmen menjalankan ini. Selain itu, keamanan berolahraga saat pandemi COVID-19 merupakan hal yang penting, yang berkemungkinan besar bergantung pada tingkat paparan dari lingkungan. Olahraga ringan, dilakukan dengan jarak sosial yang tepat, penutup wajah, sanitasi tangan, dan strategi desinfeksi, harus tetap dipromosikan secara luas oleh pejabat kesehatan masyarakat (Hew-Butler et al, 2020).

Berdasarkan latar belakang tersebut, tujuan dari kegiatan ini adalah untuk memberikan edukasi tentang prinsip dalam berolahraga dan pilihan kegiatan olahraga yang tepat di masa pandemi serta untuk memberikan arahan dalam membangun komitmen berolahraga. 


\section{MASALAH}

Alasan kami memilih masyarakat umum sebagai target edukasi karena pada masa pandemi COVID-19 banyak orang yang mengalami penurunan aktivitas fisik dan mengalami penurunan frekuensi berolahraga. Hal tersebut terjadi karena masyarakat kesulitan dalam memulai dan berkomitmen dalam berolahraga serta adanya pembatasan dalam melakukan aktivitas diluar ruangan selama pandemi COVID-19. Pembatasan aktivitas terjadi karena penularan COVID-19 terjadi dengan cepat dan kesadaran masyarakat Indonesia dalam hal menerapkan protokol kesehatan masih rendah. Aktivitas di luar ruangan tidak disarankan dan olahraga di rumah sering membosankan bagi banyak orang sehingga membangun komitmen untuk rutin berolahraga menjadi sulit. Meskipun demikian, olahraga tetap harus dilakukan untuk menjaga dan meningkatkan sistem imun tubuh. Oleh sebab itu, kami memilih melakukan kegiatan untuk menyebarkan informasi kepada masyarakat berkaitan dengan olahraga yang tepat di masa pandemi COVID-19.

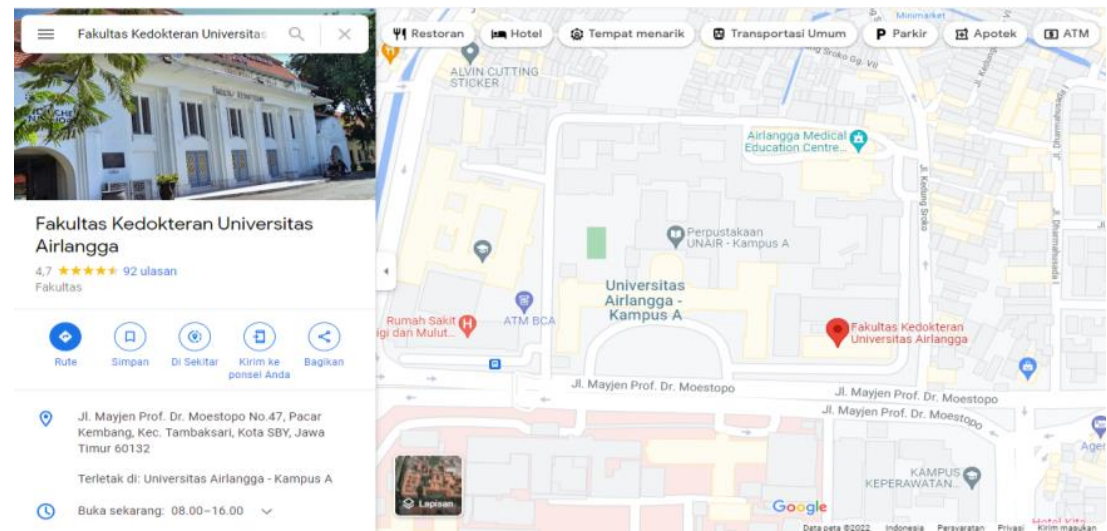

Gambar 2.1 Peta Lokasi Kegiatan Pengabdian Kepada Masyarakat.

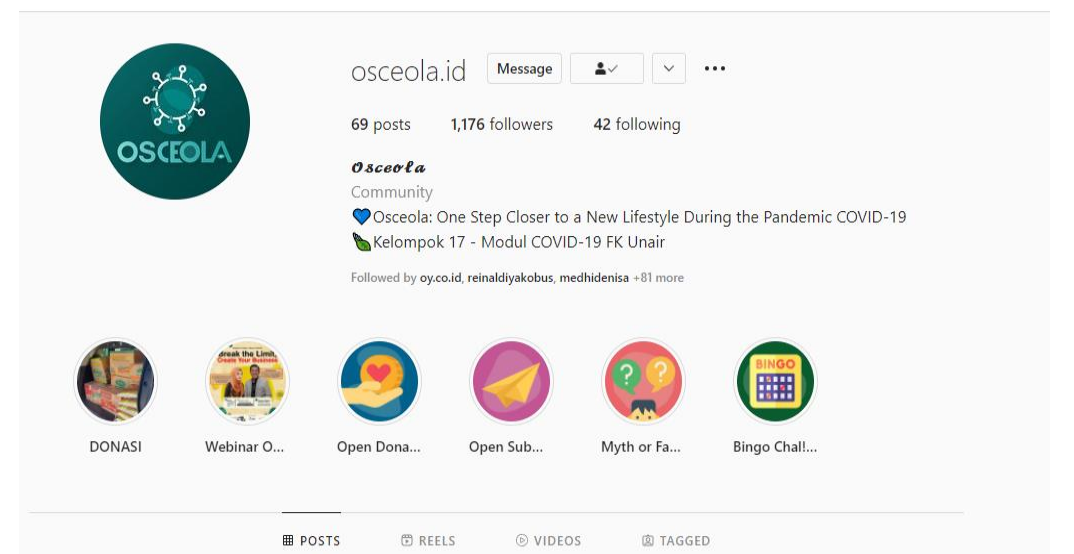

Gambar 2.2 Target Edukasi Kegiatan Pengabdian Masyarakat.

\section{METODE}

\section{a. Tahap Persiapan}

Tahap persiapan dari kegiatan ini adalah mencari permasalahan terkait olahraga di masa pandemi COVID-19, merancang kegiatan yang sesuai, mencari narasumber. Kami membuat dan menyebarkan form pretest untuk mengetahui tingkat pengetahuan masyarakat mengenai olahraga di masa pandemi. 


\section{b. Tahap Pelaksanaan}

Kegiatan Stay Healthy Series dilaksanakan baik secara luring di Fakultas Kedokteran Universitas Airlangga Surabaya maupun secara daring menggunakan platform Instagram dan juga Google Forms. Kegiatan ini berlangsung mulai bulan Mei hingga bulan Juli 2021. Target dari kegiatan ini adalah pengguna aktif media sosial instagram, mahasiswa Fakultas Kedokteran Universitas Airlangga Surabaya, dan masyarakat umum. Kegiatan ini terdiri dari wawancara dan pembuatan video edukasi.

Wawancara awal dilakukan secara langsung dengan memperhatikan protokol kesehatan terhadap 7 mahasiswa Fakultas Kedokteran Universitas Airlangga terkait kebiasaan olahraga mereka terutama pada saat pandemi COVID-19.Video hasil wawancara juga kami publikasikan melalui platform Instagram osceola.id dengan judul Osceola Bertanya : A Challenge to Stay Healthy. Video ini mendapatkan total sebanyak 319 kali tayangan terhitung hingga tanggal 29 Juli 2021.

Pemaparan video edukasi dilakukan untuk umum secara daring melalui platform Instagram mengenai tips berolahraga disaat pandemi COVID-19, yang ditujukan untuk pengguna aktif media sosial instagram, mahasiswa Fakultas Kedokteran Universitas Airlangga Surabaya dan masyarakat luas. Materi ini dibawakan oleh dr. Abdul Jabbar Al-Hayyan, Sp.KFR, sebagai dosen pengajar dari Fakultas Kedokteran Universitas Airlangga. Video ini ditampilkan melalui platform Instagram osceola.id dengan 1.176 pengikut. Video ini berjudul Expert Talk about Exercise during COVID-19 Pandemic dengan sebanyak 245 viewers terhitung hingga tanggal 29 Juli 2021.

c. Tahap Evaluasi

Evaluasi kegiatan dilakukan melalui post test secara daring yang diisi oleh 34 responden dengan diberikan beberapa pertanyaan yang sesuai dengan materi yang sudah dibawakan oleh pemateri pada saat pemaparan video edukasi untuk mengetahui sejauh apa pemahaman partisipan terkait dengan materi olahraga disaat pandemi COVID-19. Kegiatan edukasi ini dilaksanakan oleh dosen dan juga mahasiswa kedokteran Fakultas Kedokteran Universitas Airlangga.

\section{HASIL DAN PEMBAHASAN}

a. Wawancara Awal

Kami melakukan wawancara secara langsung terhadap 7 mahasiswa Fakultas Kedokteran Universitas Airlangga dengan tetap memperhatikan protokol kesehatan. Kami melakukan wawancara dengan tema seputar kebiasaan olahraga mereka terutama disaat pandemi COVID-19. Hampir seluruh partisipan wawancara kami menyukai olahraga. Frekuensi olahraga yang dilakukan oleh partisipan beragam, mulai dari satu bulan sekali, satu minggu sekali, hingga 3 kali dalam satu minggu. Jenis olahraga yang biasa dilakukan adalah jogging, badminton, futsal, dan workout.

Para partisipan menyampaikan manfaat yang didapat setelah berolahraga antara lain badan terasa lebih segar dan bugar, lebih bersemangat, dan lebih tidak cepat mengantuk saat kuliah. Sebagian besar partisipan lebih sering olahraga diluar ruangan (outdoor) dibanding di dalam ruangan (indoor), dan biasa dilakukan di sekitar rumah, di pantai, dan di alun-alun kota. Para partisipan menyampaikan 
bahwa mereka sudah melaksanakan protokol kesehatan saat melakukan kegiatan olahraga. Beberapa partisipan menambahkan bahwa akibat dari pandemi COVID-19, kondisi ini mengakibatkan terhambatnya aktivitas olahraga mereka.

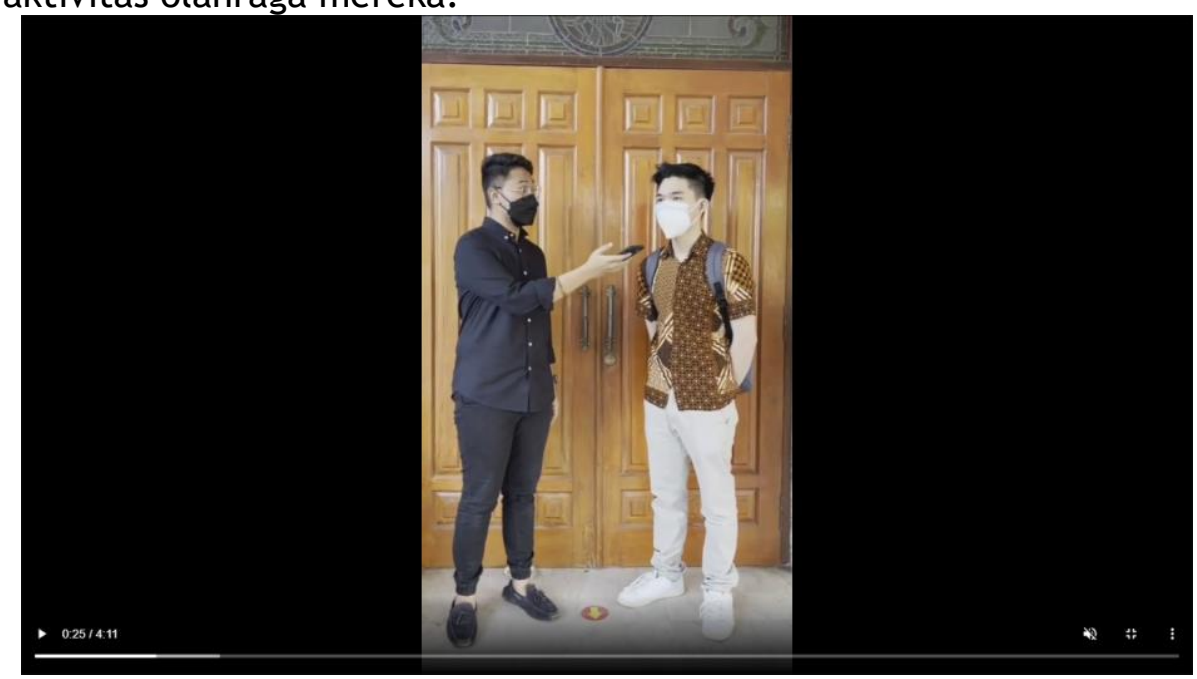

Gambar 4.1 Foto Kegiatan Wawancara Awal

\section{b. Video Edukasi}

Video edukasi dibuat bersama dengan dr. Abdul Jabbar Al-Hayyan, Sp.KFR, sebagai dosen pengajar dari Fakultas Kedokteran Universitas Airlangga, yang menampilkan materi mengenai tips berolahraga disaat pandemi COVID-19.

Cara agar tidak terkena COVID-19 saat sedang berolahraga adalah dengan tetap menerapkan protokol kesehatan berupa cuci tangan, menggunakan masker, menjauhi kerumunan. Terdapat pula kriteria VDJ (Ventilasi, Durasi, dan Jarak) yang mempengaruhi risiko terpapar oleh COVID-19. Dalam menghindari penularan COVID-19, yang terpenting adalah dengan mengurangi risiko paparan, baru setelah itu dapat menerapkan kegiatan lain seperti saat berolahraga. Olahraga yang tepat untuk dilakukan saat pandemi yaitu semua jenis olahraga, asal dilakukan sesuai dengan panduan yang tepat. Terdapat studi yang menunjukkan bahwa orang yang berolahraga dengan intensitas sedang secara teratur memiliki angka kejadian infeksi saluran nafas atas yang lebih rendah. Tanda bahwa intensitas olahraga yang sedang yaitu masih bisa berbicara, tetapi tidak bisa nyanyi.

Olahraga yang paling baik adalah olahraga yang kita lakukan. Pada saat pandemi COVID-19 ini, lebih disarankan untuk berolahraga di dalam rumah, antara lain skipping, jalan di tempat, lari di tempat, latihan beban tubuh (sit up, push up, squat, pull up). Tantangan yang paling sulit untuk berolahraga adalah untuk memulai. Apabila ingin memulai latihan, maka tetapkan target yang ringan terlebih dahulu, baru bisa menaikkan target perlahan secara perlahan. Salah satu trik untuk berolahraga adalah dengan mencari teman, misalnya dengan zoom atau video call. Cara lain apabila memiliki dana lebih adalah dengan ikut kelas zoom berbayar.

Faktor yang perlu diperhatikan saat sedang berolahraga di masa pandemi COVID-19 adalah bertemu orang lain atau tidak, ventilasi tempat berolahraga, durasi dan jarak apabila bertemu dengan orang 
lain. Kekurangan olahraga di dalam ruangan adalah ventilasi udara tidak sebaik olahraga diluar ruangan, dan apabila berolahraga di luar ruangan sebaiknya tidak ada orang lain. Faktor lain yang diperhatikan saat berolahraga antara lain kontak dekat yang sering, penggunaan alat bersama-sama, durasi kontak, tempat berolahraga, jumlah atlet yang terlibat, dan juga kepatuhan terhadap protokol kesehatan. Pada pasien yang terkena COVID-19 dengan gejala ringan dapat dilakukan latihan pernapasan, dan pada pasien yang tanpa gejala dapat melakukan kegiatan fisik sesuai kemampuan masing-masing. Apabila pasien timbul dengan gejala berat dapat berkonsultasi lebih lanjut ke dokter spesialis fisik dan rehab medik.

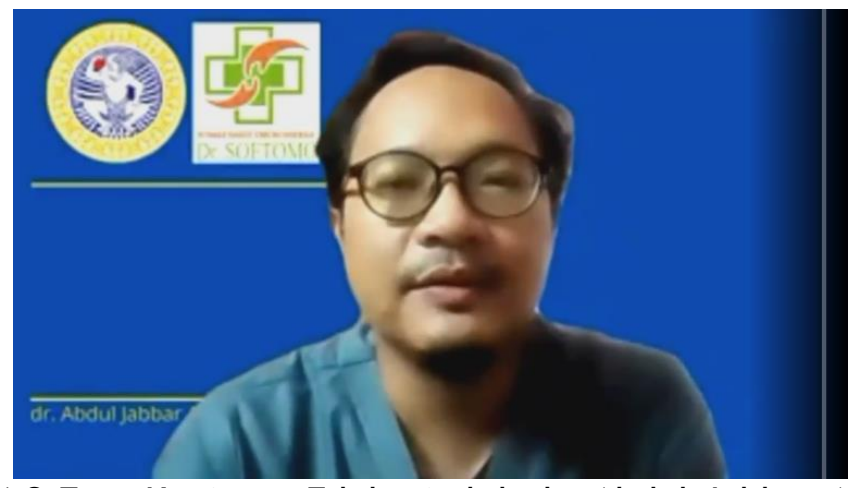

Gambar 4.2 Foto Kegiatan Edukasi oleh dr. Abdul Jabbar Al-Hayyan, Sp.KFR

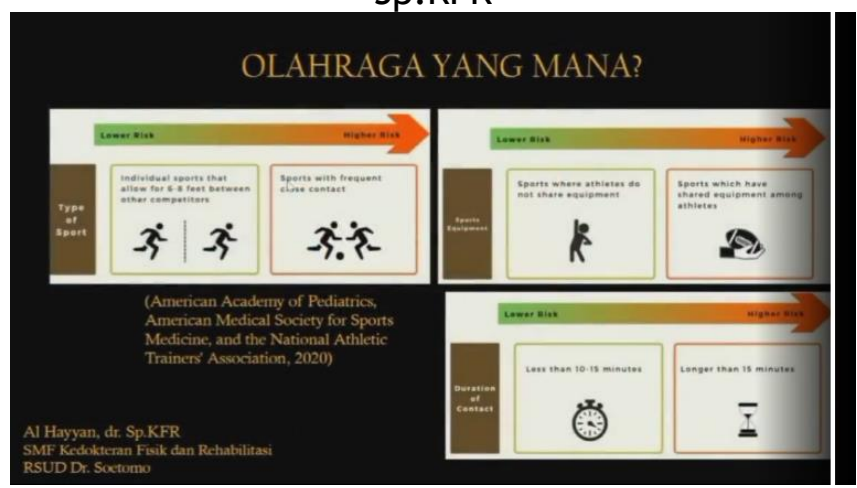

Gambar 4.3 Foto Kegiatan Edukasi seputar Olahraga di Masa Pandemi

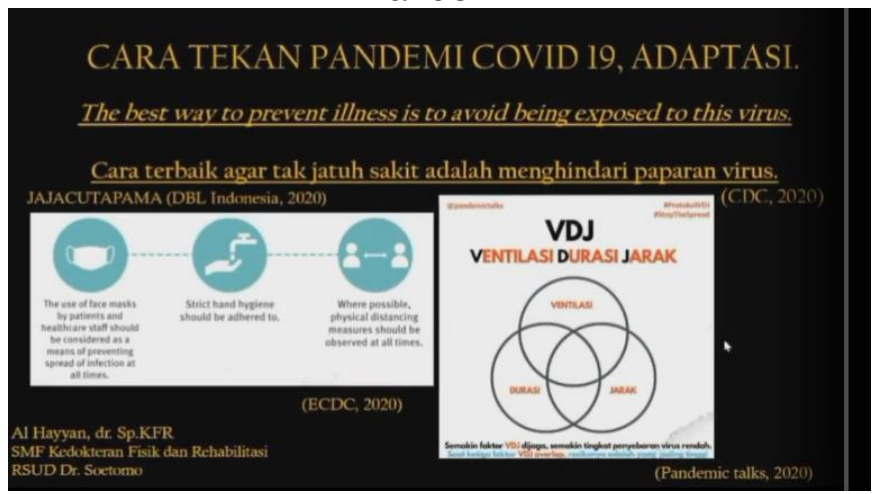

Gambar 4.4 Foto Kegiatan Edukasi Menjaga Kesehatan di Masa Pandemi 


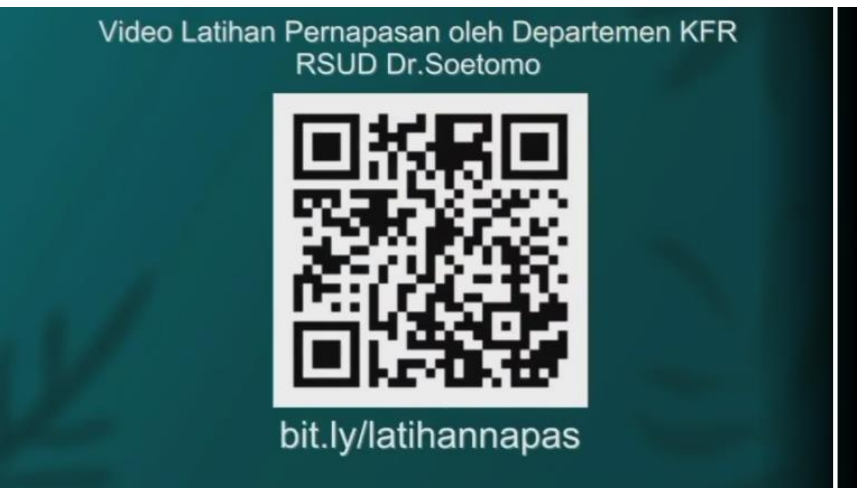

Gambar 4.5 Video Latihan Pernafasan untuk Pasien COVID-19

c. Evaluasi Kegiatan

Evaluasi Kegiatan dilakukan menggunakan Kuesioner Osceola Expert Talk about Exercise during COVID-19 Pandemic melalui platform Google Formulir, yang disebarkan melalui media sosial panitia. Terdapat total 34 responden yang mengisi kuesioner yang diberikan.

Tabel 1. Hasil Kuesioner Pre-Test Osceola Expert Talk about Exercise during COVID-19 Pandemic

\begin{tabular}{ccc}
\hline Pre-test & Frekuensi & Presentase (\%) \\
\hline 0 & 0 & 0 \\
20 & 0 & 0 \\
40 & 2 & $5.88 \%$ \\
60 & 0 & 0 \\
80 & 1 & $2,94 \%$ \\
100 & 3 & $8,82 \%$ \\
120 & 3 & $8,82 \%$ \\
140 & 4 & $11,76 \%$ \\
160 & 5 & $14,70 \%$ \\
180 & 6 & $17,64 \%$ \\
200 & 10 & $29,41 \%$ \\
\hline
\end{tabular}

Tabel 2. Hasil Kuesioner Post-Test Osceola Expert Talk about Exercise during COVID-19 Pandemic

\begin{tabular}{ccc}
\hline Post-test & Frekuensi & Presentase (\%) \\
\hline 0 & 0 & 0 \\
20 & 0 & 0 \\
40 & 0 & 0 \\
60 & 0 & 0 \\
80 & 0 & 0 \\
100 & 0 & 0 \\
120 & 0 & 0 \\
140 & 2 & $5,88 \%$ \\
160 & 0 & 0 \\
180 & 3 & $8,82 \%$ \\
200 & 29 & $85,29 \%$ \\
\hline
\end{tabular}


Kuesioner Pre-Test dan Post-Test Osceola Expert Talk about Exercise during COVID-19 Pandemic terdiri atas 10 pertanyaan dengan nilai masing masing soal 20 poin. Berdasarkan Tabel 1 menunjukkan bahwa pada $5.88 \%$ atau 2 orang responden memiliki nilai 40/200, 2,94\%atau 1 orang responden dengan nilai $80 / 200,8,82 \%$ atau 3 orang responden dengan nilai $100 / 200,8,82 \%$ atau 3 orang responden dengan nilai $120 / 200,11,76 \%$ atau 4 orang responden dengan nilai $140 / 200,14,70 \%$ atau 5 orang responden dengan nilai $160 / 200,17,64 \%$ atau 6 orang responden dengan nilai 180/200 dan $29,41 \%$ atau 10 orang responden dengan nilai $200 / 200$. Terdapat hasil yang beragam yang dihasilkan oleh para responden sebelum menonton video edukasi.

Berdasarkan Tabel 2 menunjukkan bahwa pada 5.88\% atau 2 orang responden memiliki nilai $140 / 200,8,82 \%$ atau 3 orang responden dengan nilai $180 / 200$, dan $85,29 \%$ atau 29 orang responden dengan nilai $200 / 200$. Terdapat peningkatan pada frekuensi dan persentase responden yang mencapai nilai tinggi dibandingkan pada Tabel 1. Dengan tidak ada responden yang memiliki nilai dibawah 140/200, dan juga meningkatnya responden dengan nilai 200/200 dibandingkan pada Tabel 1, hasil tersebut menunjukkan bahwa hampir seluruh responden yang sudah menonton video edukasi memiliki pemahaman dan pengetahuan yang sesuai dengan materi yang disampaikan dalam video edukasi. Maka dapat disimpulkan bahwa tujuan dari kegiatan ini yaitu untuk memberikan edukasi tentang prinsip dalam berolahraga dan pilihan kegiatan olahraga apa yang tepat serta arahan dalam membangun komitmen berolahraga dapat dicapai dengan baik

Hasil evaluasi berdasarkan materi yang dibawakan pada Osceola Expert Talk about Exercise during COVID-19 Pandemic

Tabel 3. Hasil Kuesioner Responden terhadap Osceola Expert Talk about Exercise during COVID-19 Pandemic Pertanyaan No.1

\begin{tabular}{cccc}
\hline Skala & Uraian & Jumlah & Presentase (\%) \\
\hline 5 & Sangat Baik & 22 & $64,70 \%$ \\
4 & Baik & 11 & $32,35 \%$ \\
3 & Cukup & 1 & $2,94 \%$ \\
2 & Kurang & 0 & 0 \\
1 & Sangat Kurang & 0 & 0 \\
\hline
\end{tabular}

Tabel 3 menunjukkan keberagaman penilaian terhadap materi yang disampaikan pada Osceola Expert Talk about Exercise during COVID-19 Pandemic. Penilaian menggunakan rentang 1-5 yang berarti semakin tinggi penilaian maka kategori semakin baik, demikian sebaliknya. Berdasarkan hasil kuesioner, sebanyak 22 responden atau sebesar $64,70 \%$ menyatakan bahwa materi yang dibawakan sangat baik atau mendapat skor 5.Terdapat 11 responden lain atau sebesar $32,35 \%$ yang menyatakan baik dan 1 responden lain atau 2.94\% responden memberikan penilaian cukup. Tidak ada responden yang memberikan penilaian kurang pada materi ini. Hasil ini menunjukkan bahwa tujuan untuk memberikan edukasi kepada masyarakat telah 
tercapai. Hal ini dikarenakan responden merasakan bahwa materi telah cukup baik yang memiliki arti dapat dipahami dan diimplementasikan.

Hasil evaluasi berdasarkan kesesuaian materi terhadap kondisi pandemi COVID-19 yang dibawakan pada Osceola Expert Talk about Exercise during COVID-19 Pandemic

Tabel 4. Hasil Kuesioner Responden terhadap Osceola Expert Talk about Exercise during COVID-19 Pandemic Pertanyaan No.2

\begin{tabular}{cccc}
\hline Skala & Uraian & Jumlah & Presentase (\%) \\
\hline 5 & Sangat Baik & 26 & $76,47 \%$ \\
4 & Baik & 8 & $23,52 \%$ \\
3 & Cukup & 0 & 0 \\
2 & Kurang & 0 & 0 \\
1 & Sangat Kurang & 0 & 0 \\
\hline
\end{tabular}

Dari hasil Tabel 4, dapat disimpulkan bahwa materi yang dibawakan pada 'Osceola Expert Talk about Exercise during COVID19 Pandemic' dinilai sangat sesuai dengan kondisi pandemi COVID-19 yang dihadapi saat ini. Hal ini terlihat dari hasil kuesioner evaluasi dimana $76,47 \%$ responden memberikan penilaian sangat baik dan 23,52\% lainnya memberi penilaian baik. Tidak didapatkan responden yang memberikan penilaian cukup, kurang, maupun sangat kurang. Dengan kesesuaian materi pada expert talk ini dengan kondisi yang dihadapi oleh masyarakat luas saat ini, diharapkan dapat menambah pengetahuan tentang berolahraga semasa pandemi dan dapat diimplementasikan dalam kegiatan berolahraga sehari-hari dengan risiko penularan COVID-19 yang seminimal mungkin.

Hasil evaluasi berdasarkan kebermanfaatan acara pada Osceola Expert Talk about Exercise during COVID-19 Pandemic

Tabel 5. Hasil Kuesioner responden terhadap Osceola Expert Talk about Exercise during COVID-19 Pandemic Pertanyaan No.3

\begin{tabular}{cccc}
\hline Skala & Uraian & Jumlah & Presentase (\%) \\
\hline 5 & Sangat Baik & 25 & $73,52 \%$ \\
4 & Baik & 9 & $26,47 \%$ \\
3 & Cukup & 0 & 0 \\
2 & Kurang & 0 & 0 \\
1 & Sangat Kurang & 0 & 0 \\
\hline
\end{tabular}

Tabel 5 menunjukkan bahwa seluruh responden menyatakan Osceola Expert Talk about Exercise during COVID-19 Pandemic memiliki kebermanfaatan yang baik dan cukup baik bagi masyarakat. Pada 73,52\% responden atau sebanyak 25 responden menyatakan sangat bermanfaat, sedangkan 9 responden lainnya atau sebesar $26,47 \%$ menyatakan baik. Tidak ada dari responden yang memberikan penilaian kurang untuk kebermanfaatannya. Hasil ini menunjukkan bahwa tujuan dari kegiatan ini tercapai yaitu masyarakat merasakan manfaat dari edukasi yang disampaikan dan mendapatkan ilmu baru. Kebermanfaatan yang dirasakan oleh responden selaras dengan hasil evaluasi sebelumnya yaitu juga menilai materi dengan baik dan sesuai keadaan. 
Berdasarkan dari hasil kuesioner yang didapatkan baik itu pretest,post-test, dan evaluasi maka didapatkan bahwa Osceola Expert Talk about Exercise during COVID-19 Pandemic telah memenuhi tujuan. Hasil post-test menunjukkan terdapat perbaikan dibandingkan dengan hasil pre-test. Jumlah responden yang menjawab benar semua atau skor 200 mencapai 85,29\% dari responden yang artinya ada kenaikan sekitar 3 kali lipat dibandingkan dengan hasil pre-test yang hanya pada $29,41 \%$ responden. Pada sisi lain, hasil post-test menunjukkan bahwa nilai yang paling rendah adalah 140 dan hanya pada $5.88 \%$ responden. Hal ini menunjukkan peningkatan dibandingkan dengan hasil pre-test yang nilai terendahnya adalah 40 dan responden yang mendapatkan nilai kurang dari sama dengan 140, sebesar $29,44 \%$ responden. Maka perbedaan hasil ini yang menjadi indikator ketercapaian dari kegiatan Osceola Expert Talk about Exercise during COVID-19 Pandemic

Peningkatan ini selaras dengan hasil evaluasi responden untuk kegiatan ini. Materi, kesesuaian materi dengan kondisi pandemi COVID-19, dan kebermanfaatan kegiatan dinilai mulai dari cukup hingga sangat baik. Hal yang mendukung penilaian evaluasi ini adalah pada kegiatan awal sebelum Osceola Expert Talk about Exercise during COVID-19 Pandemic, kami melakukan survei publik sehingga mulai dari pemilihan materi hingga kesesuaian dengan keadaan dapat tercapai. Materi bersumber dari jawaban responden survei dan berdasarkan itu maka gambaran pengetahuan masyarakat dan kebiasaan yang dilakukan bisa didapatkan. Selanjutnya, pertanyaan dalam survei juga sesuai dengan keadaan pandemi saat ini maka hal ini yang turut mendukung pemilihan materi yang disampaikan sesuai dengan keadaan saat ini. Kesesuaian materi yang sesuai dengan keadaan dapat mendukung penerimaan dari materi edukasi. Pada akhirnya, responden dapat merasakan kebermanfaatan dari Osceola Expert Talk about Exercise during COVID-19 Pandemic dikarenakan dapat menerima dengan baik. Sehingga, materi yang disampaikan dapat diimplementasikan dan menjadi pedoman dalam tindakan selanjutnya.

\section{KESIMPULAN}

Dengan mengangkat tema Exercise during COVID-19 Pandemic, Osceola melakukan serangkaian kegiatan yaitu melakukan wawancara dan membuat video edukasi bersama narasumber ahli (Osceola Expert Talk). Osceola Expert Talk about Exercise during COVID-19 Pandemic hadir di masyarakat untuk memberikan edukasi tentang berolahraga yang tepat di masa pandemi. Dengan kegiatan ini, maka berdasarkan hasil post-test didapatkan peningkatan hingga tiga kali lipat dibanding pre-test untuk responden yang mendapatkan nilai sempurna. Berdasarkan evaluasi, seluruh responden juga merasakan kebermanfaatan kegiatan ini yaitu dengan menilai baik dan sangat baik. Maka, hasil ini menunjukkan adanya peningkatan pemahaman tentang bagaimana berolahraga yang tepat pada masa pandemi. Sehingga, tujuan kedua dari kegiatan ini untuk membangun komitmen berolahraga juga turut tercapai karena masyarakat telah tahu tahapan yang tepat. 


\section{SARAN}

Kegiatan edukasi ini dapat dilakukan secara berkelanjutan dengan massa yang lebih luas lagi, sehingga informasi terkait pentingnya olahraga di masa pandemi COVID-19 dan prinsip penting dalam olahraga dapat memberikan manfaat serta diaplikasikan oleh masyarakat dalam menjaga kesehatan.

\section{DAFTAR PUSTAKA}

Brand, R., Timme, S., \& Nosrat, S. (2020). When Pandemic Hits: Exercise Frequency and Subjective Well-Being During COVID-19 Pandemic. Frontiers in psychology, 11, 570567. doi:10.3389/fpsyg.2020.570567

Chen, P., Mao, L., Nassis, G.P., Harmer, P., Ainsworth, B.E. and Li, F., (2020). Coronavirus disease (COVID-19): The need to maintain regular physical activity while taking precautions. Journal of sport and health science, 9(2), p.103. doi:10.1016/j.jshs.2020.02.001

Fallon, K., (2020). Exercise in the time of COVID-19. Aust J Gen Pract, 49(Suppl 13), pp.1-2. doi: 10.31128/AJGP-COVID-13.

Firdaus, Kamal. (2012). Psikologi Olahraga. Padang: Fakultas Ilmu Keolahragaan Universitas Negeri Padang Press.

Guan WJ, Ni ZY, Hu Y, Liang WH, Ou CQ, He JX, et al. (2020). Clinical characteristics of 2019 novel coronavirus infection in China. MedRxiv. doi: 10.1056/NEJMoa2002032

Hew-Butler, T., Smith-Hale, V., Van Sumeren, M., Sabourin, J., \& Levy, P. (2020). Is Exercise the Best Medicine during a COVID-19 Pandemic? Comment on Constandt, B.; Thibaut, E.; De Bosscher, V.; Scheerder, J.; Ricour, M.; Willem, A. Exercising in Times of Lockdown: An Analysis of the Impact of COVID-19 on Levels and Patterns of Exercise among Adults in Belgium. Int. J. Environ. Res. Public Health 2020, 17, 4144. International journal of environmental research and public health, 17(16), 5730. doi:10.3390/ijerph17165730

Lim, M. A., \& Pranata, R. (2021). Sports activities during any pandemic lockdown. Irish journal of medical science, 190(1), 447-451. doi:10.1007/s11845-020-02300-9

Vancini, R. L., Andrade, M. S., Viana, R. B., Nikolaidis, P. T., Knechtle, B., Campanharo, C., de Almeida, A. A., Gentil, P., \& de Lira, C. (2021). Physical exercise and COVID-19 pandemic in PubMed: Two months of dynamics and one year of original scientific production. Sports medicine and health science, 3(2), 80-92. doi : 10.1016/j.smhs.2021.04.004.

Wicaksono, Arif. (2020). Aktivitas fisik yang aman di masa pandemi covid 19. Pontianak: Ilmu Keolahragaan Undiksha. http://dx.doi.org/10.23887/ jiku.v9i3.39579

Yuliana. (2020). Olahraga yang aman di masa pandemi covid-19 untuk meningkatkan imunitas tubuh. Bali: Bali membangun bali. http://ejournal.baliprov.go.id/index.php/jbmb/article/view/112 